\title{
Metabolomics using Gas chromatography-mass spectrometry and antibacterial activity of nine Ocimum taxa of Dakshin Dinajpur district, West Bengal, India
}

\section{Tanmay Chowdhury*}

Cytogenetics \& Plant Breeding Section, Department of Sericulture, Raiganj University, Raiganj, Uttar Dinajpur-733134 (West Bengal), India

\section{Goutam Kumar Basak}

Department of Microbiology, Raiganj University, Raiganj University, Raiganj, Uttar Dinajpur733134 (West Bengal), India

\section{Putchen Dakshinamoorthy Deepalakshmi}

Waters India Pvt Ltd, 36A, II Phase, Peenya Industrial Area, Bangalore, 560058, India

Soumen Saha

Cytogenetics \& Plant Breeding Section, Department of Sericulture, Raiganj University, Raiganj, Uttar Dinajpur-733134 (West Bengal), India

\section{Amitava Mandal}

Molecular Complexity Laboratory, Department of Chemistry, Raiganj University, Raiganj, Uttar Dinajpur-733134 (West Bengal), India

*Corresponding author. Email: tanmay000@gmail.com

\section{Article Info}

https://doi.org/10.31018/ jans.v13i1.2508

Received: January 11, 2021

Revised: February 12, 2021

Accepted: February 18, 2021

\section{How to Cite}

Chowdhury, T. et al. (2021). Metabolomics using Gas chromatography-mass spectrometry and antibacterial activity of nine Ocimum taxa of Dakshin Dinajpur district, West Bengal, India. Journal of Applied and Natural Science, $13(1)$ : 127 - 136. https://doi.org/10.31018/jans.v13i1.2508

\begin{abstract}
Ocimum traditionally known as Holy Basil or Tulsi is an available herb plenty across the country. Traditionally, it is used against a number of human diseases. In this present study, the metabolites present in the ethanolic extracts of nine Ocimum taxa, $O$. tenuiflorum L. (Green and purple type) two morphotypes of $O$. basilicum L., (Babu and Marua tulsi) two morphotypes of $O$. gratissimum L. (Ram and Ajowan tulsi) and each one from O. americanum L. (Bon tulsi), O. $\times$ africanum Lour. (Lebu tulsi), and O. kilimandscharicum Guerke.grown naturally in Dakshin Dinajpur district, West Bengal, India were identified using Gas chromatography-mass spectrometry (GC-MS). Among the identified metabolites, carbohydrates, aliphatic alcohols, aliphatic acids, fused ring aromatic hydrocarbon, amino acids, phenolic compounds, quinone, steroids, terpenoids and vitamin $E$ were the chief constituents. The occurrence of these metabolites describes the high biological activity of Ocimum species. Furthermore, in vitro antibacterial activities were also identified against four bacterial strains, Staphylococcus aureus (MTCC 96), Bacillus cereus (MTCC 1305), Proteus vulgaris (MTCC 1771) and Escherichia coli (MTCC 2939). Tested bacterial strains were taken from the Institute of Microbial Technology, Chandigarh, India The results indicated that the ethanolic extracts of all the nine Ocimum taxa have satisfactory minimum inhibitory concentration (MIC) values against the tested microorganisms. O. tenuiflorum has the highest $(91.03 \%)$ metabolic content whereas $O . \times$ africanum has the minimum. This would definitely serve as a scientific basis of the traditional use of basil against human ailments.
\end{abstract}

Keywords: Antibacterial activity, Ethanolic extracts, GC-MS, MIC, Ocimum

\section{INTRODUCTION}

The use of Basil (Tulsi) against human diseases traced back from the period of Rigveda (ca. $1500 \mathrm{BC}$ ) and has mythological significance in Hindu rituals. Ocimum is one of the most versatile genuses of medicinal and strongly aromatic plants available plenty in the tropical and subtropical region of Asia and central South America, comprises annual or perennial, much branched herb and shrub, native to the subtropical region of Asia (Labra et al., 2004). So far in India about nine species of Ocimum have been reported (Rana amd Blazquez, 2015). Traditionally Ocimum species have been used for the treatment of common cold and cough, fever, 
bronchitis, asthma, tuberculosis, earache, dysentery, ringworm infection and memory enhancer (Vidyarthi et al., 2013; Chowdhury et al., 2016, Chowdhury et al., 2019) and are well documented in Ayurveda. Reports have claimed that Ocimum extracts have antibacterial, antifungal (Vieira et al., 2014; Chaturvedi et al., 2018; Chintaluri and Komarraju, 2019) insecticidal and most interestingly insect (against mosquitoes) repellent properties (Bhavya et al., 2018; Benelli et al., 2019; Lim et al., 2019). Additionally, O. sanctum has adaptogenic, antidiabetic, anticancer and anti-inflammatory, antistress, anti-carcinogenic, hepato-protective, radioprotective, neuro-protective, cardio-protective and immunomodulatory effects (De Lima et al., 2014; Singh et al., 2017; Singh and Chaudhuri, 2018).

Recently, research in Ocimum has accelerated after finding its HIV-1 reverse transcriptase inhibitory activity (Sonar et al., 2017) and decrease platelets aggregation induced by ADP and thrombin (Tohti et al., 2006). Fresh or dried Basil leaves can be used as a spice and in different culinary applications. It is an important source of essential oils which are broadly used by perfume and cosmetic industries like body spray, hair dressings, soaps, dental creams, mouth washes, flavouring beverages, food preservative and in pharmaceuticals. It is also a very good source of proteins, carbohydrates, minerals, fat, fiber, mucilage, pigments and moderately high concentration of vitamins such as A, C, $\mathrm{E}$ and K (Singh and Chaudhuri, 2018; Zahran et al., 2020).

Plants' extracts have always been a better choice against human ailments. However, the advent of modern synthetic drugs has superseded the place. The indiscriminate use of antimicrobial agents has resulted in the emergence of a number of drug-resistant bacteria and fungi. Advanced antimicrobial agents with novel mode of biochemical action must be developed to overcome the increasing risk of resistant pathogenic microbes. As natural products have an imprint of biological structural space, they may be the best alternative in future against synthetic drugs. Frequent studies have revealed that different Ocimum essential oils are active against several bacteria as well as against yeasts and fungi (Stanojevic et al. 2017; Chintaluri and Komarraju, 2019; Vieira et al., 2014; Mohr et al., 2017). Diets rich in selected natural antioxidants such as polyphenols, flavonoids, vitamin $\mathrm{C}$ and $\mathrm{E}$ are related to reducing cardiovascular risk, other chronic diseases and certain types of cancer. This leads to the revival of interest to intake plants-based dietary supplement which serves as an alternative source of vitamins, minerals and natural antioxidants. In addition, people nowadays prefer organic cultivation and natural food additives, hence naturally derived antimicrobial agents such as Basil are becoming more important in antimicrobial packaging as they present a perceived lower risk to consumers (Sappakul et al., 2003; Nguefack et al., 2009).

Most of the earlier workers from India and abroad have shown the variation of metabolites (phenylpropanoids and terpenes) of different Ocimum species and their varieties (Mondello et al., 2002; Padalia and Verma, 2011; Verma et al., 2013; Verma et al., 2016). This may lead to exclusion or increase/decrease in the quantity of some important molecules such as carbohydrates, amino acids and vitamins in the extracts of the natural population of Ocimum species under the influence of local ecology. A complete study of the metabolites of Basil extracts from its natural habitat under a given ecological condition and their antimicrobial activities are therefore an unrest demand in the contemporary literature. The present work is reporting the detail identification and quantitation of metabolites present in the ethanolic extracts of Ocimum using GC-MS and antibacterial activities (MIC values) of nine species grown naturally in Dakshin Dinajpur district, West Bengal, India.

\section{MATERIALS AND METHODS}

\section{Plant materials}

After an extensive survey, the fresh mature leaves of nine taxa of tulsi (Ocimum sp.) were collected from various places of Dakshin Dinajpur, West Bengal, India, during flowering stage in August-September, 2019. Two morphotypes of O. tenuiflorum L. (Green and purple type) two morphotypes of O. basilicum L. (/Babu and Marua tulsi) two morphotypes of $O$. gratissimum $\mathrm{L}$. (Ram and Ajowan tulsi) and one each from O. americanum L. (Bon tulsi), O. $\times$ africanum Lour. (Lebu tulsi), and O. kilimandscharicum Guerke. (Karpur tulsi) were taken for this study. All the specimens were identified by the Botanical Survey of India, Kolkata. Voucher specimens of each taxa was submitted in the North Bengal University herbarium at Department of Botany, West Bengal, India.

\section{Preparation of plant ethanolic extracts}

The harvested leaves of different samples were dried under shade and ground to powder in a grinder. Extraction was performed at room temperature in closed vials using ethanol as the solvent for 7 days. Ethanol was recovered under reduced pressure by a rotary evaporator (Buchi RotavaporR-3; Buchi Labortechnik AG, Flawil, Switzerland) at $45^{\circ} \mathrm{C}$. Yellow-greenish ethanolic extracts were lyophilized and kept in vials at $4{ }^{\circ} \mathrm{C}$.

\section{Gas chromatograph - Mass spectrometry (GC-MS) analysis}

The chemical compositions of the nine ethanolic extracts of Ocimum taxa were identified using GC-MS followed by NIST library search. Each sample was lyophilised and suspended in $100 \mathrm{~mL}$ of methanol. 100 $\mu \mathrm{L}$ of this diluted sample was completely dried by pass- 
ing nitrogen gas. All samples were derivatised using 30 $\mu \mathrm{L}$ pyridine and $50 \mu \mathrm{L}$ BSTFA:TMCS (99:1) and incubated for $60 \mathrm{~min}$ at $60{ }^{\circ} \mathrm{C}$. GC analyses were carried out on the derivatised samples in an Agilent system 7890A equipped with a DB 5 MS capillary column (30 $\mathrm{mL} \times 0.25 \mathrm{~mm}$ ID $\times 0.25 \mu \mathrm{m}$ film thicknesses dimension). The helium flow rate was maintained at $1.0 \mathrm{~mL} /$ min. The initial column temperature was maintained at $70{ }^{\circ} \mathrm{C}$ with 2 min hold time. Then ramp the temperature to $150{ }^{\circ} \mathrm{C}$ at the rate of $5{ }^{\circ} \mathrm{C} / \mathrm{min}$ and again to $280{ }^{\circ} \mathrm{C}$ at the rate of $3{ }^{\circ} \mathrm{C} / \mathrm{min}$ with 2 min hold time and finally to $320{ }^{\circ} \mathrm{C}$ temperature at the rate of $10{ }^{\circ} \mathrm{C}$ with $3 \mathrm{~min}$ hold time. $1.0 \mu \mathrm{L}$ of the sample was subjected to GC-MS using the split mode (split ratio 10:1). The GC-MS analysis was done on the Agilent system 5975CMSD (Mass selective detector). Ionization for MS was Electron Impact Ionization with ionization energy of $70 \mathrm{eV}$ and mass analyzer was single quadrupole. Mass spectra scan range was from $30 \mathrm{~m} / \mathrm{z}-600 \mathrm{~m} / \mathrm{z}$ with +ve polarity. The interface temperature was set at $310^{\circ} \mathrm{C}$, source temperature at $250{ }^{\circ} \mathrm{C}$ and quadruple temperature at $150{ }^{\circ} \mathrm{C}$. Prior to the acquisition, MSD was auto tuned with FC43 (perfluorotributylamine). The GC-MS data was deconvoluted using AMDIS v2.7 (Automated Mass Spectral Deconvolution and Identification System) software. AMDIS extracts spectral data from co-eluting compounds by performing noise reduction and background subtraction. The deconvoluted spectra were then compared with the spectra available in the National Institute Standard and Technology (NIST 2011) library to identify the compounds. Relative percent of metabolites in a mixture was calculated by dividing peak area of the metabolite to the total peak area of all metabolites and multiply the result by 100 .

\section{Test microorganisms}

The antibacterial activity was evaluated against four microorganisms including Gram-positive Bacillus cereus (MTCC 1305), Staphylococcus aureus (MTCC 96) and Gram-negative Proteus vulgaris (MTCC 1771) and Escherichia coli (MTCC 2939). All the bacterial strains were obtained from the Institute of Microbial Technology, Chandigarh, India. Bacterial strains were maintained on nutrient agar (HiMedia, Mumbai, India) slants and the cultures were stored at $4{ }^{\circ} \mathrm{C}$ with a subculture period of 30 days.

\section{Determination of antibacterial activity by disc diffusion method}

In vitro antibacterial activity of ethanolic extracts of nine Ocimum taxa were studied against two Gram-positive and two Gram-negative bacterial strains by agar disc diffusion method according to the protocol by National Committee for Clinical Laboratory Standards, 1997 (Patel 2016). The nutrient agar (HiMedia Laboratories Limited, Mumbai, India) was autoclaved at $121^{\circ} \mathrm{C}$ and
$1 \mathrm{~atm}$ for 30 minutes. The sterile nutrient media was kept away maintaining the temperature at $45-50{ }^{\circ} \mathrm{C}$, after that $100 \mu \mathrm{L}$ of bacterial suspension containing $10^{8}$ colony-forming units (CFU)/mL were mixed with sterile liquid nutrient agar and poured into the sterile petri dishes. Upon solidification of the media, filter discs (5 $\mathrm{mm}$ diameter) were individually soaked with different concentration $(25,50,75$ and $100 \mathrm{mg} / \mathrm{mL})$ of each Ocimum extract and placed on the solidified nutrient agar media plates. The different concentrations were made by dissolving the lyophilized extracts in $10 \%$ dimethyl sulfoxide (DMSO). Throughout the experiment, solvent control (DMSO) was used that showed no inhibition. The plates were incubated for 24 hours at $37^{\circ} \mathrm{C}$. The diameter of the zone of inhibition (including disc diameter of $5 \mathrm{~mm}$ ) was measured with a scale. Each experiment was done thrice to minimize any experimental error and the mean values were taken.

\section{Determination of minimum inhibitory concentration (MIC)}

The minimum inhibitory concentration was measured by Broth Micro dilution susceptibility method. A serial dilution of plant extracts was made in Nutrient broth medium. Then $1 \mathrm{~mL}$ of standard (0.5 McFarland) bacterial suspension was inoculated into each of these tubes. A similar nutrient broth tube without plant extract was also inoculated and used as a negative control. The tubes were incubated at $37{ }^{\circ} \mathrm{C}$ for 24 hours. The lowest concentration of plant extract, which inhibited bacterial growth was considered as minimum inhibitory concentration. Final confirmation was done by streaking on nutrient agar medium.

\section{RESULTS AND DISCUSSION}

\section{Chemical composition}

A detail analyses of GC-MS data (Fig. 1; Table 1) showed that in the ethanolic extracts of nine naturally grown Ocimum taxa, carbohydrates were the major components for O. tenuiflorum (Krishna tulsi), O. americanum (Bon tulsi), O. gratissimum (Ram tulsi), O. basilicum (Marua tulsi) and $0 . \times$ africanum (Lebu tulsi) representing $91.03 \%, 77.71 \%, 51.31 \%, 43.06 \%$ and $38.77 \%$ of the total metabolites present in the extracts respectively. $\alpha-D$-glucose was found to be the highest carbohydrate in $0 . \times$ africanum and 0 . americanum with natural abundance of $17.23 \%$ and $55.32 \%$ respectively whereas in Krishna tulsi (O. tenuiflorum ) fructose was the main carbohydrate with $27.24 \%$ natural abundance. However O. gratissimum (Ram tulsi) and $O$. basilicum (Marua tulsi) had $\beta$-D-glucose $17.76 \%$ and $26.98 \%$ respectively. This anomeric difference in the carbohydrate content was remarkable, it might be due to any dissimilarity in biological structure space at enzymes from where it is being synthesized. The higher 
Chowdhury, T. et al. / J. Appl. \& Nat. Sci. 13(1): 127 - 136 (2021)

Table 1. Relative quantitation of metabolites present in different Ocimum taxa from GC-MS analyses.

\begin{tabular}{|c|c|c|c|c|c|c|c|c|c|}
\hline \multirow[t]{2}{*}{ Compounds } & \multicolumn{9}{|c|}{ Relative percentage composition } \\
\hline & OG & OG1 & OxA & OA & OB & OB1 & OTP & OTG & OK \\
\hline D-Allofuranose & - & - & - & - & - & - & 0.41 & - & - \\
\hline$\beta$-D-allopyranose & - & - & - & 0.24 & - & - & - & - & - \\
\hline Arabinitol & - & - & 0.01 & 0.04 & 2.22 & - & - & 0.01 & - \\
\hline D-Arabinopyranose & - & - & - & - & - & - & 0.06 & - & - \\
\hline L-(-)-Arabitol & - & - & - & - & - & - & 0.68 & - & - \\
\hline Fructose & 5.08 & 3.47 & 3.56 & 3.65 & - & 4.2 & 27.24 & - & - \\
\hline Furanone & - & - & - & - & - & - & 0.03 & - & - \\
\hline D-galactose & - & - & - & - & - & 0.56 & 0.04 & - & 2.7 \\
\hline D-gluconic acid & - & - & - & 0.2 & - & - & 0.36 & - & - \\
\hline$\alpha-D-G l u c o s e$ & - & - & 17.23 & 55.32 & - & - & 22.15 & 0.02 & - \\
\hline$\beta$-D-glucose & 26.98 & 16.14 & 4.23 & 4.29 & - & 17.76 & 2.65 & 0.73 & 2.78 \\
\hline D-Mannitol & - & - & - & 0.49 & - & - & - & - & 1.53 \\
\hline$\alpha-D-(+)-M a n n o s e$ & - & - & 13.75 & 0.5 & - & 14 & 0.24 & 0.22 & - \\
\hline Myo-Inositol & 0.01 & - & - & 0.3 & - & 0.18 & 1.16 & - & - \\
\hline D-Psicose & - & - & - & 4.04 & - & - & - & - & - \\
\hline D-Sorbitol & - & - & - & - & - & - & 0.55 & - & - \\
\hline L-(-)-Sorbose & 5.9 & - & - & 6.91 & - & - & 9.1 & - & - \\
\hline Sucrose & - & - & - & - & - & 1 & 5.65 & - & - \\
\hline a-D-(-)-Tagatose & - & 3.46 & - & - & - & 4.95 & 19.02 & - & - \\
\hline D-(+)-Talofuranose & - & - & - & - & - & - & 0.37 & - & - \\
\hline a-D-(+)-Talose & 13.35 & - & - & - & - & 0.14 & 1.31 & - & - \\
\hline L-Threitol & - & 0.34 & - & 1.73 & - & - & - & - & 0.21 \\
\hline Xylitol & - & - & - & - & - & 0.26 & - & - & 1.75 \\
\hline L-Alanine & - & - & - & - & - & - & 0.25 & - & - \\
\hline L-Norleucine & - & - & - & - & - & - & 0.01 & - & - \\
\hline L-Proline & - & - & - & 0.74 & - & - & 1.23 & - & - \\
\hline L-Homoproline & - & - & - & - & - & - & - & 0.05 & - \\
\hline L-Threonic acid & - & - & - & - & - & - & 0.14 & - & - \\
\hline L-Threonine & - & - & - & - & - & - & 0.08 & - & - \\
\hline L-Valine & - & - & - & 0.08 & - & - & - & - & - \\
\hline Glycerol & 0.48 & 0.07 & 10.87 & 7.36 & 15.42 & 7.17 & 5.45 & 21.84 & 53.29 \\
\hline Hexadecenol & 7.1 & - & 10.06 & 3.87 & 12.76 & 4.62 & - & 9.94 & 6.3 \\
\hline Meso-Erythritol & - & - & 0.74 & - & 5.27 & 0.48 & - & 0.14 & 5.13 \\
\hline Acetic acid & - & - & - & - & - & 0.74 & - & - & - \\
\hline Butanedioic acid & 0.72 & 0.3 & - & 0.36 & - & - & 0.27 & 0.09 & - \\
\hline Butanoic acid & - & - & - & - & - & - & 0.03 & - & - \\
\hline Dodecanoic acid & - & - & - & - & - & 0.37 & - & - & - \\
\hline Eicosanoic acid & - & - & - & 0.04 & - & - & - & 0.93 & - \\
\hline Hexadecanoic acid & 10.37 & 6.87 & 6.8 & 0.39 & 29.64 & 13.46 & 0.34 & 15.01 & 0.69 \\
\hline Linoleic acid & 0.13 & - & 2.14 & - & 2.39 & - & - & 2.56 & 0.45 \\
\hline a-Linolenic acid & 0.94 & 7.05 & 14.47 & 2.94 & 12.64 & 3.80 & - & 12.63 & 7.78 \\
\hline Octadecanoic acid & 1.92 & 0.48 & 2.49 & 1.55 & 6.26 & 2.83 & 0.07 & 8.62 & 2.08 \\
\hline n-Pentadecanoic acid & - & - & - & - & - & 0.12 & - & - & - \\
\hline Propanedioic acid & - & - & - & - & - & - & 0.11 & - & - \\
\hline
\end{tabular}

Contd...... 


\begin{tabular}{|c|c|c|c|c|c|c|c|c|c|}
\hline Propanoic acid & 0.04 & 1.77 & 1.77 & 1.05 & 1.93 & 0.02 & 0.5 & 0.05 & 1.42 \\
\hline Benzoic acid & - & - & - & 0.14 & - & 0.19 & 0.01 & - & - \\
\hline Cinnamic acid & 0.21 & - & - & - & - & - & - & - & - \\
\hline Naphthalene & - & - & - & 0.07 & - & - & - & - & - \\
\hline Tert-Butylhydroquinone & - & 0.09 & - & - & - & - & - & - & - \\
\hline Caffeic acid & - & 0.21 & - & - & - & - & - & - & - \\
\hline Catechol & - & - & - & - & - & - & 0.08 & - & - \\
\hline Eugenol & 12.46 & - & - & - & - & - & - & 8.61 & - \\
\hline Methyl eugenol & - & - & - & - & - & 15.53 & - & - & - \\
\hline Vanillin & 0.71 & - & - & - & - & - & - & - & - \\
\hline$\alpha$-Tocopherol & 2.39 & 1.4 & 0.4 & 0.16 & - & 1.01 & - & 0.5 & 0.44 \\
\hline Ergosterol & - & - & 0.88 & - & - & 0.65 & - & 1.26 & - \\
\hline Stigmasterol & 0.88 & 2.29 & 1.51 & - & - & 0.79 & - & 3.59 & - \\
\hline$\beta$-Sitosterol & 2.7 & 3.36 & 2.5 & 0.99 & 3.62 & 2.55 & - & 4.53 & 6.31 \\
\hline a-Amyrin & 1.42 & - & - & - & - & 0.79 & - & - & - \\
\hline Carvacrol & - & 0.54 & - & - & - & - & - & - & - \\
\hline Caryophyllene oxide & 1.36 & - & - & - & - & - & - & 0.48 & - \\
\hline$\beta$-Elemene & - & - & - & - & - & - & - & 1.15 & - \\
\hline Germacrene D & - & - & - & - & - & - & - & 0.01 & - \\
\hline Norpinene & - & - & - & - & - & 0.01 & - & - & - \\
\hline Phytol & - & 14.68 & 2.94 & - & - & 0.54 & - & - & - \\
\hline a-Selinene & - & - & - & - & - & - & - & 0.43 & - \\
\hline$\beta$-Selinene & - & - & - & - & - & - & - & 0.64 & - \\
\hline Squalene (Precursor) & 1.69 & 4.78 & - & - & - & - & - & - & - \\
\hline Tau-Cadinol & - & - & - & - & - & 0.36 & - & - & - \\
\hline Thymol & - & 29.8 & 0.02 & - & - & - & - & 0.69 & - \\
\hline Others & 3.16 & 2.91 & 3.79 & 2.55 & 7.83 & 0.91 & 0.43 & 5.28 & 7.14 \\
\hline
\end{tabular}

OG- O. gratissimum (Ram tulsi), OG 1 - O. gratissimum (Ajowan tulsi), O×A- O. × africanum (Lebu tulsi), OA- O. americanum (Bon tulsi), OB- O. basilica (Babu tulsi), $\mathrm{OB}_{1}$ - O. basilicum (Marua tulsi), OTP- O. tenuiflorum (Krishna tulsi), OTG- O. tenuiflorum (Radha tulsi), OKO. kilimandschericum (Karpur tulsi).

percentage of carbohydrate showed the high food value of Ocimum species.

Hexadecanoic acid generally known as the palmitic acid is an antioxidant and it has selective antitumor activity (Pereira et al., 2014; Ravi and Krishnan, 2017). The present study showd a higher abundance of palmitic acid (29.64\%) in Babu tulsi indicating that this extract might be used directly to suppress tumor cells growth. $\alpha$-linolenic acid has been reported to have anti inflammatory effects (Solomon et al., 2012; Pauls et al., 2018). Our this finding ascribes the local use of Tulsi leaves to treat inflammation. From GC-MS analysis it was found that all the nine Ocimum extracts contained fatty acids in higher proportion signifying the ability of Ocimum species to reduce blood cholesterol level and serves as an antioxidant as also reported earlier (Mensink et al., 2003; Suanarunsawat et al., 2009; Chao et al., 2016).
In the present investigation, we found the presence of some amino acids like L-alanine, L-proline, Lnorleucine, L-threonine, L-threonic acid, L-valine and LHomoproline. O. americanum contained $0.74 \%$ Lproline and $0.08 \%$ L-valine. O. tenuiflorum contained only $0.05 \%$ pipecolic acid. O. tenuiflorum contained $0.24 \%$ L-alanine, $1.23 \%$ L-proline, $0.01 \%$ L-norleucine, $0.14 \%$ L-threonic acid and $0.08 \%$ L-threonine. Since amino acids are the building blocks of proteins, the occurrence of amino acids with higher yields indicated the presence of proteins in Tulsi. Tulsi might, therefore, be considered as a promising source of plant derived proteins.

Sterols were also found in the ethanolic extracts of different species. $O . \times$ africanum was found to contain $0.88 \%$ ergosterol, $1.51 \%$ stigmasterol, and $2.50 \% \beta$ sitosterol. But 0 . americanum, O. kilimandschericum and $O$. basilicum (Babu tulsi) all three had only $\beta$ - 


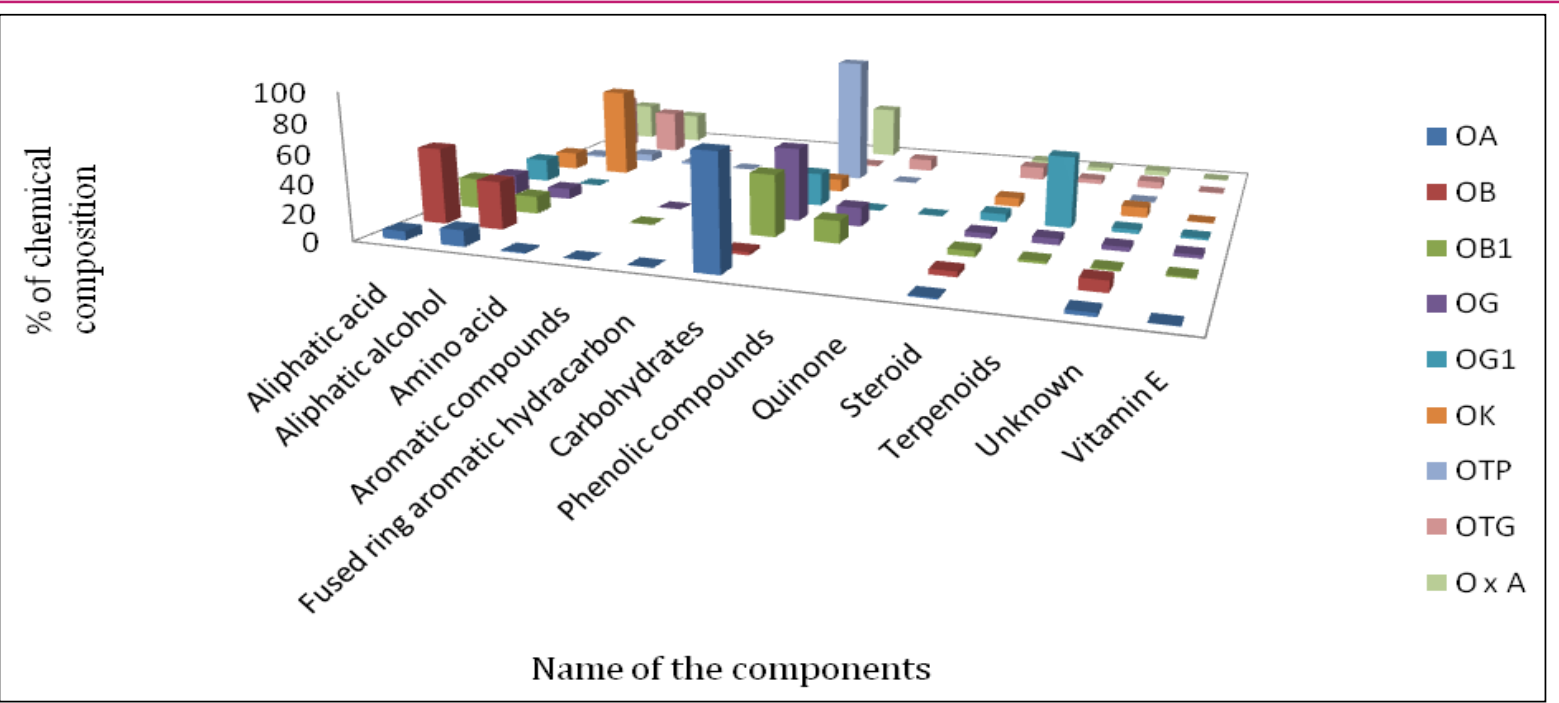

Fig. 1. Abundance of different metabolites in the ethanolic extracts of nine Ocimum taxa (OA- O. americanum (Bon tulsi), OB- O. basilicum (Babu tulsi), OB1- O. basilicum (Marua tulsi), OG- O. gratissimum (Ram tulsi), OG1- O. gratissimum (Ajoyan tulsi), OK- O. kilimandschericum (Karpur tulsi), OTP- O. tenuiflorum (Krishna tulsi), OTG- O. tenuiflorum (Radha tulsi), OxA- O. $x$ africanum (Lebu tulsi).

sitosterol as $0.99 \%, 6.31 \%$ and $3.62 \%$ respectively. 0 . basilicum (Marua tulsi) and 0 . tenuiflorum (Radha tulsi) had ergosterol $(0.65 \%, 1.26 \%)$, stigmasterol $(0.79 \%$, $3.59 \%)$ and $\beta$-sitosterol $(2.55 \%, 4.53 \%)$. Stigmasterol $(0.88 \%)$ and $\beta$-sitosterol $(2.70 \%)$ were the main constituents of steroid in O. gratissimum (Ram tulsi). O. gratissimum (Ajowan tulsi) contained $\beta$-sitosterol (3.36\%) and stigmasterol (2.29\%). Among these sterols especially, stigmasterol has proven anti-poisonous/antivenom effects (Gomes et al., 2007; Shabbir et al., 2014). The present study thus provide a scientific base to the folk medicine practice of using Tulsi leaves against poisonous insects/strings.

Vitamin $E$ ( $\alpha$-Tocopherol) was found to be present in all the Ocimum taxa studied except in O. tenuiflorum (Krishna tulsi) and O. basilicum (Babu tulsi). It was observed that $O$. gratissimum (Ram tulsi) contained maximum amount of $\alpha$-tocopherol $(2.39 \%)$ followed by $O$. gratissimum (Ajowan tulsi) (1.40\%), O. basilicum (Marua tulsi) (1.01\%), O. tenuiflorum (Radha tulsi) $(0.50 \%)$, O. kilimandschericum $(0.44 \%), 0 . \times$ africanum $(0.40 \%)$ and 0 . americanum $(0.16 \%)$. The presence of vitamin $E$ signified the use of Tulsi extracts in medicines/cosmetics to treat skin diseases. $\alpha$-Tocopherol is the most biologically active form of vitamin $E$ and is the second most common form of vitamin $E$ in the diet. It is a fat soluble antioxidant. Thus continuous use of Tulsi extracts may, therefore, lower the risk of pancreatitis, leukaemia and various forms of skincancers by scavenging the unwanted free radicals (Lai et al., 2014; Hu et al., 2015 Elsy et al., 2017).

A total of 12 terpenoids were identified in the nine Ocimum ethanolic extracts. These terpenoids were also responsible for aroma in different Tulsi species in conjugation with naphthalene. In O. × africanum, O. basili- cum (Marua tulsi), O. tenuiflorum (Radha tulsi), O. gratissimum (Ram tulsi) and O. gratissimum (Ajowan tulsi) have $2.96 \%, 1.7 \%, 3.41 \%, 4.48 \%$ and $49.8 \%$ terpenoids respectively. Among them, phytol, $\alpha$-amyrin, $\beta$ elemene, squalene (triterpene precursor) and thymol exhibit maximum abundance of $2.94 \%, 0.79 \%, 1.15 \%$, $1.69 \%$ and $29.8 \%$ respectively. Another interesting terpenoid found in $O$. tenuiflorum (Radha tulsi) and $O$. gratissimum (Ram tulsi) was caryophyllene that has wide antimicrobial effects (Dahham et al., 2015). Ram tulsi also contained $1.69 \%$ squalene and $1.42 \%$ aamyrin. The co-occurrence of squalene hydrocarbon and $\alpha$-amyrin confirmed the biosynthetic pathway of pentacyclic triterpenoids such as a-amyrin from squalene. The contemporary medicinal chemistry research is full of anti tumour activities and enzymatic activities of pentacyclic triterpenoids (Mandal et al., 2012). Presence of a-amyrin in Ram and Marua tulsi indicates the anti tumour activities of Tulsi extracts. The occurrence of different terpenoids in tulsi extract explains the traditional use of tulsi against bacterial/fungal infections, cough and cold, bronchitis and in asthma. Phenolic compounds such as caffeic acid, catechol, vanillin, eugenol and methyl eugenol were found in the different studied Ocimum species. These naturally occurring phenols attribute to the high anti oxidant activities of tulsi.

\section{Antimicrobial activity}

The antibacterial activities of nine ethanolic Ocimum extracts determined against four bacterial strains by Disc diffusion method are given in Table 2. The ethanolic extracts of Ocimum under study showed promising results against all the bacterial strains. From the inhibitory values, it was clear that $O$. americanum (Bon 
Chowdhury, T. et al. / J. Appl. \& Nat. Sci. 13(1): 127 - 136 (2021)

Table 2. Zone of inhibition ( $\mathrm{mm}$ ) study of ethanolic extracts of nine ocimum taxa against different four bacterial strains.

\begin{tabular}{|c|c|c|c|c|c|c|c|c|c|c|c|c|c|c|c|c|}
\hline \multirow{4}{*}{$\begin{array}{c}\text { Ocimum } \\
\text { sp. }\end{array}$} & \multicolumn{4}{|c|}{ S. aureus } & \multicolumn{4}{|c|}{ B. cereus } & \multicolumn{4}{|c|}{$P$. vulgaris } & \multicolumn{4}{|c|}{ E. coli } \\
\hline & \multicolumn{4}{|c|}{$\begin{array}{l}\text { Concentration } \\
(\mathrm{mg} / \mathrm{mL})\end{array}$} & \multicolumn{4}{|c|}{$\begin{array}{l}\text { Concentration } \\
(\mathrm{mg} / \mathrm{mL})\end{array}$} & \multicolumn{4}{|c|}{$\begin{array}{l}\text { Concentration } \\
(\mathrm{mg} / \mathrm{mL})\end{array}$} & \multicolumn{4}{|c|}{$\begin{array}{l}\text { Concentration } \\
(\mathrm{mg} / \mathrm{mL})\end{array}$} \\
\hline & 25 & 50 & 75 & 100 & 25 & 50 & 75 & 100 & 25 & 50 & 75 & 100 & 25 & 50 & 75 & 100 \\
\hline & \multicolumn{16}{|c|}{ Inhibition zone (mm) } \\
\hline OA & - & - & - & 7 & - & - & 6 & 8 & - & 7 & 8 & 10 & - & 6 & 7 & 9 \\
\hline $\mathrm{OB}$ & - & - & 7 & 8 & - & - & - & 7 & - & - & - & 8 & - & - & - & 7 \\
\hline OB1 & - & - & 7 & 8 & - & - & - & 8 & - & - & 7 & 9 & - & 6 & 8 & 9 \\
\hline OG & - & 6 & 7 & 9 & - & - & - & 8 & - & - & - & 7 & - & - & 7 & 9 \\
\hline OG1 & - & 6 & 8 & 9 & - & - & 7 & 9 & - & - & - & 8 & 6 & 7 & 8 & 10 \\
\hline OK & - & - & - & 7 & - & 7 & 9 & 10 & - & - & 7 & 9 & - & 6 & 7 & 9 \\
\hline OTP & - & 7 & 8 & 10 & - & - & 8 & 10 & - & - & 7 & 9 & 6 & 7 & 9 & 11 \\
\hline OTG & - & - & 7 & 9 & - & 7 & 8 & 9 & - & - & - & 8 & - & 6 & 8 & 9 \\
\hline$O \times A$ & - & 6 & 8 & 10 & - & - & 7 & 8 & - & 6 & 8 & 10 & - & - & 7 & 9 \\
\hline
\end{tabular}

OA- O. americanum (Bon tulsi), OB- O. basilicum (Babu tulsi), $\mathrm{OB}_{1}-$ O. basilicum (Marua tulsi), OG- O. gratissimum (Ram tulsi), OG ${ }_{1-}$ O. gratissimum (Ajowan tulsi), OK- O. kilimandschericum (Karpur tulsi), OTP- O. tenuiflorum (Krishna tulsi), OTG- O. tenuiflorum (Radha tulsi), O×A- O. $\times$ africanum (Lebu tulsi).

Table 3. Antibacterial activity of nine ocimum taxa against four bacterial strains with MIC (mg/ml) values.

\begin{tabular}{|c|c|c|c|c|}
\hline & S. aureus & B. cereus & P. vulgaris & E. coli \\
\hline Ocimum sp. & MIC (mg/mL) & MIC (mg/mL) & MIC (mg/mL) & MIC (mg/mL) \\
\hline $\mathrm{OA}$ & 100 & 75 & 50 & 50 \\
\hline OB & 75 & 100 & 100 & 100 \\
\hline OB1 & 75 & 100 & 75 & 50 \\
\hline OG & 50 & 100 & 100 & 75 \\
\hline OG1 & 50 & 75 & 100 & 25 \\
\hline OK & 100 & 50 & 75 & 50 \\
\hline OTP & 50 & 75 & 75 & 25 \\
\hline OTG & 75 & 50 & 100 & 50 \\
\hline $\mathrm{O} \times \mathrm{A}$ & 50 & 75 & 50 & 75 \\
\hline
\end{tabular}

OA- O. americanum (Bon tulsi), OB- O. basilicum (Babu tulsi), $\mathrm{OB}_{1}-$ O. basilicum (Marua tulsi), OG- O. gratissimum (Ram tulsi), OG - $^{-}$ O. gratissimum (Ajowan tulsi), OK- O. kilimandschericum (Karpur tulsi), OTP- O. tenuiflorum (Krishna tulsi), OTG- O. tenuiflorum (Radha tulsi), O×A- O. $\times$ africanum (Lebu tulsi).

tulsi) was most effective against $P$. vulgaris and $E$. coli. Interestingly, O. gratissimum (Ajowan tulsi) and O. tenuiflorum (Krishna tulsi) showed maximum inhibition against $E$. coli with $25 \mathrm{mg} / \mathrm{mL}$ MIC values (Table 3).

Against $B$. cereus, O. kilimandschericum (Karpur tulsi) and $O$. tenuiflorum (Radha tulsi) showed most effective inhibition having $50 \mathrm{mg} / \mathrm{mL}$ MIC values. O. $\times$ africanum was found to be the most effective (MIC $50 \mathrm{mg} / \mathrm{mL}$ ) against $P$. vulgaris and $S$. aureus, on the other hand, O. gratissimum (Ram tulsi) was most effective (MIC 50 $\mathrm{mg} / \mathrm{mL}$ ) against $S$. aureus only. E. coli, $P$. vulgaris and $S$. aureus was most susceptible to $O$. basilicum (Marua tulsi) at $50 \mathrm{mg} / \mathrm{mL}$ and $75 \mathrm{mg} / \mathrm{mL}$ MIC respectively, whereas $O$. basilicum (Babu tulsi) was found to show highest value of MIC of $75 \mathrm{mg} / \mathrm{mL}$ against $S$. aureus. The presence of different terpenoids and fatty acids such as caryophyllene, thymol, b-elemene, linolenic acid and higher proportion of eugenol and methyl euge- nol might be the chief cause for the higher activity of different Ocimum species (Singh et al., 2005). These antibacterial results implied the significance of determining the biological efficacy of same plant cultivated under varied conditions in a different region. Although the exact mechanisms behind the antimicrobial efficacy of these Ocimum extracts are not certain, there are few scientific proposals available in contemporary literature. Complete destruction of cell membrane opens out the bacterial intracellular materials such as protein, lipids and nucleic acids (Oyedemi et al., 2009). Notably, the lipophilic terpenoids and phenylpropanoids may induce cell membrane damage, thereby bringing equilibrium of inorganic ions (Trombetta et al., 2005; Chouhan et al., 2017). An advantage of using plants' extracts against pathogenic bacteria as against to specific antibacterial drug is the incredibly lesser risk of developing resistance since the extracts are a mixture of various an- 
timicrobial compounds having different mechanism (Bakkali et al., 2008; Rahman and Kang, 2009).

\section{Conclusion}

The metabolites from the ethanolic extracts of dried leaves of nine Ocimum taxa were separated and identified using GC-MS. In this analysis, a number of compounds were identified such as carbohydrates, amino acids, alcohols, aliphatic acids, aromatic hydrocarbons, phenolic compounds, quinone, steroids, terpenoids, vitamin $\mathrm{E}$ etc. All the nine different Ocimum taxa showed promising antibacterial effects as shown by the MIC values. Notably, O. $\times$ africanum showed $50 \mathrm{mg} / \mathrm{mL}$ MIC values against $P$. vulgaris and $S$. aureus in the antibacterial study. The high carbohydrate content, as revealed from the GC-MS study proves the beneficial food value of Ocimum species. The study would have a high impact to gain a detail scientific knowledge about the different naturally growing Ocimum species and their chemical constituents with significant antibacterial efficacies.

\section{ACKNOWLEDGMENTS}

Authors are thankful to Raiganj University for providing laboratory facilities and Botanical Survey of India (BSI), Kolkata for identification of nine Ocimum taxa. PDD acknowledges the Department of Biotechnology-IISc Grant-in-aid Partnership Programme for utilizing GCMS.

\section{Conflict of interest}

The authors declare that they have no conflict of interest.

\section{REFERENCES}

1. Bhavya, M.L., Chandu, A.G.S. and Devi, S.S. (2018). Ocimum tenuiflorum oil, a potential insecticide against rice weevil with anti-acetylcholinesterase activity. Ind. Crop Prod. 126, 434-439. https://doi.org/10.1016/j.indcrop.20 18.10.043.

2. Benelli, G., Pavela, R., Maggi, F., Wandjou, J.G.N., KonéBamba, D., Sagratini, G., Vittori, S. and Caprioli, G. (2019). Insecticidal activity of the essential oil and polar extracts from Ocimum gratissimum grown in Ivory Coast: Efficacy on insect pests and vectors and impact on nontarget species. Ind. Crop Prod. 132, 377-385. https:// doi.org/10.1016/j.indcrop.2019.02.047.

3. Bakkali, F., Averbeck, S., Averbeck, D. and Idaomar, M. (2008). Biological effects of essential oils - a review. Food Chem. Toxicol. 46, 446-75. https://doi.org/10.1016/j.fct.2 007.09.106.

4. Chowdhury, T., Mandal, A., Jana, A.K., Roy, S.C.and De Sarker, D. (2016). Study of phyto-sociology and ecology of naturally growing Ocimum species with their conserva- tional strategies in Dakshin Dinajpur district of West Bengal. Acta Ecol. Sin. 36, 483-491. https://doi.org/10.1016/ j.chnaes.2016.08.003.

5. Chowdhury, T., Roy, S.C.and De Sarker, D. (2019). Ethnobotanical study of Dakshin Dinajpur district of West Bengal, In: Martinez, J.L., MunPoz-Acevedo, A., Mahendra Rai, M., (Eds.), Ethnobotany: Local Knowledge and Traditions. CRC Press, New Delhi, India, p132-157. https://doi.org/10.1201/9780429424069.

6. Chaturvedi, T., Kumar, A., Kumar, A., Verma, R.S., Padalia, R.C., Sundaresan, V., Chauhan, A., Saikia, D., Singh, V.R.and Venkatesha, K.T. (2018). Chemical composition, genetic diversity, antibacterial, antifungal and antioxidant activities of camphor-basil (Ocimum kilimandscharicum Guerke). Ind. Crop Prod. 118, 246-258. https:// doi.org/10.1016/j.indcrop.2018.03.050.

7. Chintaluri, A.K. and Komarraju, A.L. (2019). TLCBioautographic Detection of Antimicrobial Compounds in Essential Oils of Selected Ocimum Species. J. Essent. Oil Bear. Pl. 22, 187-199. https://doi.org/10.1080/097206 0 X.2019.1602082.

8. Chao, P.Y., Lin, J.A., Ting, W.J., Lee, H.H., Hsieh, K. Chiu, Y.W., Lai, T.J., Hwang, J.M., Liu, J.R.and Huang, C.Y. (2016). Ocimum gratissmum aqueous extract reduces plasma lipid in hypercholesterol-fed hamsters. Int. J. Med. Sci. 13(11), 819-824. https://doi.org/10.7150/ijm s. 16474

9. Chouhan, S., Sharma, K.and Guleria, S. (2017). Antimicrobial activity of some essential oils-present status and future perspectives. Medicines, 4(3), 58. https://doi.org/1 $0.3390 /$ medicines 4030058 .

10. De Lima, V.T., Vieira, M.C., Kassuya, C.A.L., Cardoso, C.A.L., Alves, J.M., Foglio, M.A., de Carvalho, J.E.and Formagio, A.S.N. (2014). Chemical composition and free radical-scavenging, anticancer and anti-inflammatory activities of the essential oil from Ocimum kilimandscharicum. Phytomedicine, 21(11), 1298-1302. https://doi.org/1 0.1016/j.phymed.2014.07.004.

11. Dahham, S.S., Tabana, Y.M., Iqbal, M.A., Ahamed, M.B., Ezzat, M.O., Majid, A.S. and Majid, A.M. (2015). The Anticancer, Antioxidant and Antimicrobial Properties of the Sesquiterpene $\beta$-Caryophyllene from the Essential Oil of Aquilaria crassna. Molecules, 20, 11808-11829. https:// doi:10.3390/molecules200711808.

12. Elsy, B., Khan, A. A. and Maheshwari, V. (2017). Vitamin $E$ isoforms ( $d \alpha$-tocopherol and $\delta$-tocotrienol) promote healing of secondary skin wounds in diabetic rats. J. Anat. Soc. India. 66, S14. https://doi.org/10.1016/j.jasi.2017.0 8.047 .

13. Gomes, A., Saha, A., Chatterjee, I. and Chakravarty, A.K. (2007). Viper and cobra venom neutralization by $\beta$ sitosterol and stigmasterol isolated from the root extract of Pluchea indica Less. (Asteraceae). Phyomedicine, 14, 637-43. https://doi.org/10.1016/j.phymed.2006.12.020.

14. Hu, F., Wu, Z., Li, G., Teng, C., Liu, Y., Wang, F., Zhao, Y. and Pang, D. (2015). The plasma level of retinol, vitamins $A, C$ and $\alpha$-tocopherol could reduce breast cancer risk? A meta-analysis and meta-regression. J. Cancer Res. Clin. Oncol. 141(4), 601-614. https://doi.org/10.1007/ s00432-014-1852-7.

15. Labra, M., Miele, M., Ledda, B., Grassi, F., Mazzei, M.and Sala, F. (2004). Morphological characterization, essential 
oil composition and DNA genotyping of Ocimum basilicum L. cultivars. Plant Sci., 167, 725-731. http://doi:10.1016/ j.plantsci.2004.04.026.

16. Lim, V., Mohd Narawi, M., Chiu, H.I., Tung, W.H., Tan, J.J. and Lee, C.K. (2019). Selected essential oils as repellents against Aedes aegypti: validation of the bioconstituents using gas chromatography. J. Essent. Oil Bear. PI. 22(4), 1058-1073. https://doi.org/10.1080/0972060X.201 9.1661796

17. Lai, G.Y., Weinstein, S.J., Albanes, D., Taylor, P.R., Virtamo, J., McGlynn, K.A. and Freedman, N.D. (2014). Association of serum $\alpha$-tocopherol, $\beta$-carotene, and retinol with liver cancer incidence and chronic liver disease mortality. Br. J. Cancer. 111, 2163-2171. https://doi.org/10.1038/bj c.2014.365.

18. Mohr, F.B.M., Lermen, C., Gazim, Z.C., Gonçalves, J.E.and Alberton, O. (2017). Antifungal activity, yield, and composition of Ocimum gratissimum essential oil. Genet. Mol. Res. 16, 1-10. https://doi.org/10.4238/gmr16019542.

19. Mondello, L., Zappia, G., Cotroneo, A., Bonaccorsi, I., Chowdhury, J.U., Yusuf, M. and Dugo, G. (2002). Studies on the essential oil bearing plants of Bangladesh, Part VIII. Composition of some Ocimum oils $O$. basilicum $L$. var. purpurascens, O. sanctum L. green, O.sanctum L. purple, O. americanum L. citral type, O. americanum L. camphor type. Flav. Fragr. J. 17, 335-40. https:// doi.org/10.1002/ffj.1108.

20. Mensink, R.P., Zock, P.L., Kester, A.D.and Katan, M.B. (2003). Effects of dietary fatty acids and carbohydrates on the ratio of serum total to HDL cholesterol and on serum lipids and apolipoproteins: a meta-analysis of 60 controlled trials. Am. J. Clin. Nutr. 77(5), 1146-1155. https:// doi.org/10.1093/ajcn/77.5.1146.

21. Mandal, A., Ghosh, S., Bothra, A.K., Nanda, A.K.and Ghosh, P. (2012). Synthesis of friedelan triterpenoid analogs with DNA topoisomerase Ila inhibitory activity and their molecular docking studies. Eur. J. Med. Chem. 54, 137-43. https://doi.org/10.1016/j.ejmech.2012.04.037.

22. Nguefack, J., Dongmo, J.L., Dakole, C.D., Leth, V., Vismer, H.F., Torp, J., Guemdjom, E.F.N., Mbeffo, M., Tamgue, O., Fotio, D. and Zollo, P.A. (2009). Food preservative potential of essential oils and fractions from Cymbopogon citratus, Ocimum gratissimum and Thymus vulgaris against mycotoxigenic fungi. Int. J. Food Microbiol. 131(2-3), 151-156. https://doi.org/10.1016/j.ijfoodmi cro.2009.02.009.

23. Oyedemi, S.O., Okoh, A.I., Mabinya, L.V., Pirochenva, G. and Afolayan, A.J. (2009). The proposed mechanism of bactericidal action of eugenol, $\square$-terpineol and g-terpinene against Listeria monocytogenes, Strepto-coccus pyogenes, Proteus vulgaris and Escherichia coli. Afr. J. Biotechnol. 8, 1280-86.

24. Padalia R.C.and Verma R.S. (2011). Comparative volatile oil composition of four Ocimum species from northern India. Nat. Prod. Res. 25, 569-75. https://doi.org/10.10 80/14786419.2010.482936.

25. Patel, J.B. (2017). Performance Standards for Antimicrobial Susceptibility Testing. Clinical and Laboratory Standards Institute, Wayne.

26. Pereira, D. M., Correia-da-Silva, G., Valentão, P., Teixeira, N.and Andrade, P. B. (2014). Palmitic acid and ergosta $-7,22-$ dien-3-ol contribute to the apoptotic effect and cell cycle arrest of an extract from Marthasterias glacialis L. in neuroblastoma cells. Mar. Drugs. 12(1), 54-68. https:// doi.org/10.3390/md12010054.

27. Pauls, S.D., Rodway, L.A., Winter, T., Taylor, C.G., Zahradka, P.and Aukema, H.M. (2018). Anti-inflammatory effects of $\alpha$-linolenic acid in M1-like macrophages are associated with enhanced production of oxylipins from $\alpha$ linolenic and linoleic acid. J. Nutr. Biochem. 57, 121-129. https://doi.org/10.1016/j.jnutbio.2018.03.020

28. Rana, V.S.and Blazquez, M.A. (2015). Essential oil composition of the aerial parts of five Ocimum species from Western India. J. Essent. Oil Bear PI. 18, 1234-1241. https://doi.org/10.1080/0972060X.2014.931255.

29. Ravi, L.and Krishnan, K. (2017). Cytotoxic potential of Nhexadecanoic acid extracted from Kigelia pinnata leaves. Asian J. Cell Biol. 12, 20-27. https://doi.org/10.39 23/ajcb.2017.20.27.

30. Rahman, A.and Kang, S.C. (2009). Inhibition of food borne pathogens and spoiling bacteria by essential oil and extracts of Erigeron ramosus (Walt.) B.S.P. J. Food. Safety. 29, 176-89. https://doi.org/10.1111/j.1745-4565.2009.0 0149.x.

31. Singh, V., Krishan, P.and Shri, R. (2017). Neuroprotective effects of Ocimum kilimandscharicum leaf extract against ischemia-reperfusion induced cerebral injury in mice. $J$. Neurol. Sci. 381, 997-998. https://doi.org/10.1016/ j.jns.2017.08.2814.

32. Singh, D.and Chaudhuri, P.K. (2018). A review on phytochemical and pharmacological properties of Holy basil (Ocimum sanctum L.). Ind. Crop Prod. 118, 367-382. https://doi.org/10.1016/j.indcrop.2018.03.048.

33. Sonar, V.P., Corona, A., Distinto, S., Maccioni, E., Meleddu, R., Fois, B., Floris, C., Malpure, N.V., Alcaro, S., Tramontano, E. and Cottiglia, F. (2017). Natural productinspired esters and amides of ferulic and caffeic acid as dual inhibitors of HIV-1 reverse transcriptase. Eur. J. Med. Chem. 130, 248-60. https://doi.org/10.1016/j.ejmech.20 17.02.054.

34. Stanojevic, L.P., Marjanovic-Balaban, Z.R., Kalaba, V.D., Stanojevic, J.S., Cvetkovic, D.J.and Cakic, M.D. (2017). Chemical composition, antioxidant and antimicrobial activity of basil (Ocimum basilicum L.) essential oil. J. Essent. Oil Bear Pl. 20(6), 1557-1569. https://doi.org/10.1016/ j.foodchem.2007.12.010.

35. Suppakul, P., Miltz, J., Sonneveld, K.and Bigger, S.W. (2003). Antimicrobial properties of basil and its possible application in food packaging. J. Agric. Food Chem. 51, 3197-07. https://dx.doi.org/10.1021/jf021038t.

36. Solomon, A., Shmueli, O., Harari, R., Ovadia, H.and Erdinest, N. (2012). Anti-inflammatory Effects of Alpha Linolenic Acid on Human Corneal Epithelial Cells. Invest Ophthalmol. Vis. Sci.53(14), 4194-4194. https:// dx.doi.org/10.1167/iovs.12-9724.

37. Suanarunsawat, T., Ayutthaya, W.D.N., Songsa, T. and Rattanamahaphoom, J. (2009). Anti-lipidemic actions of essential oil extracted from Ocimum sanctum $\mathrm{L}$. leaves in rats fed with high cholesterol diet. J. Appl. Biomed. 7, 4553. https://dx.doi.org/10.3164/jcbn.09-52.

38. Shabbir, A., Shahzad, M., Masci, P.and Gobe, G.C. (2014). Protective activity of medicinal plants and their isolated compounds against the toxic effects from the venom of Naja (cobra) species. J. Ethnopharmacol. 157: 
222-227. https://dx.doi.org/10.1016/j.jep.2014.09.039.

39. Singh, S., Malhotra, M.and Majumda, D.K. (2005). Antibacterial activity of Ocimum sanctum L. fixed oil. Indian J. Exp. Biol. 43, 835-837.

40. Tohti, I., Tursun, M., Umar, A., Turdi, S., Imin, H.and Moore, N. (2006). Aqueous extracts of Ocimum basilicum L. (sweet basil) decrease platelet aggregation induced by ADP and thrombin in vitro and rats arterio-venous shunt thrombosis in vivo. Thromb. Res. 118(6), 733-739. https:// dx.doi.org/10.1016/j.thromres.2005.12.011.

41. Trombetta, D., Castelli, F., Sarpietro, M.G., Venuti, V., Cristani, M., Daniele, C., Saija, A., Mazzanti, G. and Bisignano, G. (2005). Mechanisms of antibacterial action of three monoterpenes. Antimicrob. Agents Chemother. 49 (6), 2474-2478. https://dx.doi.org/10.1128/AAC.49.6.24742478.2005

42. Vidyarthi, S., Samant, S.S.and Sharma, P. (2013). Traditional and indigenous uses of medicinal plants by local residents in Himachal Pradesh North Western Himalaya, India. Int. J. Biodivers. Sci. Ecosyst. Serv. Manag. 9, 185200. https://doi.org/10.1080/21513732.2013.823113.
43. Vieira, P.R., de Morais, S.M., Bezerra, F.H., Ferreira, P.A.T., Oliveira, Í.R.and Silva, M.G.V. (2014). Chemical composition and antifungal activity of essential oils from Ocimum species. Ind. Crop. Prod. 55, 267-27. https:// doi.org/10.1016/j.indcrop.2015.07.004.

44. Verma, R.S., Padalia, R.C., Chauhan, A.and Thul, S.T. (2013). Exploring compositional diversity in the essential oils of 34 Ocimum taxa from Indian flora. Ind. Crops Prod. 45, 7-19. https://doi.org/10.1016/j.indcrop.20 12.12.005.

45. Verma, R.S., Kumar, A., Mishra, P., Kuppusamy, B., Padalia, R.C.and Sundaresan, V. (2016). Essential oil composition of four Ocimum spp. from the Peninsular India. J. Essent. Oil Res. 28, 35-41. https:// doi.org/10.1080/10412905.2015.1076742.

46. Zahran, E.M., Abdelmohsen, U.R., Khalil, H.E., Desoukey, S.Y., Fouad, M.A. and Kamel, M.S. (2020). Diversity, phytochemical and medicinal potential of the genus Ocimum L. (Lamiaceae). Phytochem. Rev. 19(17), 1-47. https:// doi.org/10.1007/s11101-020-09690-9. 